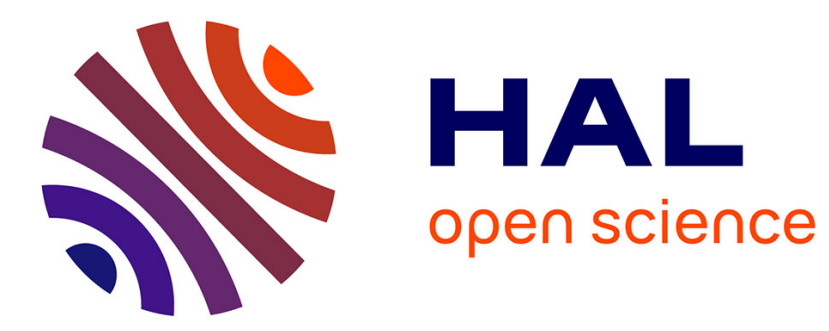

\title{
Political hierarchical processes among some Highlanders of Laos
}

Vanina Bouté

\section{To cite this version:}

Vanina Bouté. Political hierarchical processes among some Highlanders of Laos. Mandy Sadan et François Robinne (éds). Social Dynamics in the Highlands of Southeast Asia, Brill, pp. 187-208., 2007, 978-90-04-16034-7. 10.1163/ej.9789004160347.i-331.53 . hal-03554062

\section{HAL Id: hal-03554062 \\ https://hal.science/hal-03554062}

Submitted on 3 Feb 2022

HAL is a multi-disciplinary open access archive for the deposit and dissemination of scientific research documents, whether they are published or not. The documents may come from teaching and research institutions in France or abroad, or from public or private research centers.
L'archive ouverte pluridisciplinaire HAL, est destinée au dépôt et à la diffusion de documents scientifiques de niveau recherche, publiés ou non, émanant des établissements d'enseignement et de recherche français ou étrangers, des laboratoires publics ou privés. 


\section{Handbook of Oriental Studies} Handbuch der Orientalistik

Section Three

Southeast Asia

Edited by

V. Lieberman

M. C. Ricklefs

VOLUME 18
Social Dynamics in the Highlands of Southeast Asia

Reconsidering Political Systems of Highland Burma by E. R. Leach

Edited by

François Robinne and Mandy Sadan 
On the cover: Rukyen Palaung Woman (Ta-An), Northern Shan State. Photograph by François Robinne

This book is printed on acid-free paper

ISSN 0169-9571

ISBN 9789004160347

C Copyright 2007 by Koninklijke Brill NV, Leiden, The Netherlands. Koninklijke Brill NV . IDC Publishers, Martinus Nijhoff Publishers and VSP.

All rights reserved. No part of this publication may be reproduced, translated, stored in a retrieval system, or transmitted in any form or by any means, electronic, mechanical, photocopying, recording or otherwise, without prior written permission from the publisher.

Authorization to photocopy items for internal or personal use is granted by Koninklijke Brill NV provided that the appropriate fees are paid directly to The Copyright Clearance Center, 222 Rosewood Drive, Suite 910,

Danvers, MA 01923, USA.

Fees are subject to change.

PRINTED IN THE NETHERLANDS 


\section{POLITICAL HIERARCHICAL PROCESSES AMONG SOME}

HIGHLANDERS OF LAOS ${ }^{1}$

Vanina Bouté

The principal themes used by different authors to comprehend Leach's theory of socio-political oscillation between gumlao and gumsa societies are often given as land tenure or generalized exchange (cross-cousin marriage). However, neither of these criteria are valid to explain the existence of two types of social organization among the Phunoy: the first one is a society organized according to the Tay Lu's meuang system; ${ }^{2}$ the second one is nothing but autonomous villages with egalitarian lineages. I propose here a critical examination of the theory of sociopolitical oscillation in the light of the two kinds of social organisation displayed by the Phunoy. I will focus principally on the scattering of villages and the pressure on property to ask in what ways the proposals formulated among the Kachin and the Naga are not valid amongst the Phunoy, and why.

Phunoy History: The Integration of Highlanders into the LaO Kingdom

For the most part established in Phongsaly province, at the extreme north of Laos, the Phunoy comprise a group of approximately 35,000 individuals and speak a Tibeto-Burmese language. The mountainous zone of Phongsaly district is crossed from north to south by one of the most important rivers in northern Laos - the Ou river- and it is in this exact area where the Phunoy can be found. They are stock breeders and still practise shifting cultivation, despite the fact that their

1 A note on transcription: since no official system of transcription of Lao or Phunoy into English script exists, I have used one that tries to reproduce as closely as possible the Lao pronunciation with sounds that exist in English. To simplify, I did not differentiate the two types of vowels, short or long. The origin of the word is specified, when a ate the two types of vowels, short or long. The origin of the word is specif
Phunoy word is used, with a ' $\mathrm{P}$ '; words in Tai are indicated with a ' $\mathrm{T}$ '.

Phunoy word is used, with a 'P'; words in Tai are indicated with a 'T'.
2 The meuang is a fundamental territorial and political unit of the Tai populations, it can be translated as "principality', and can refer to both the territory and its centre (the town, the village). For a definition of the meuang, please refer to J.-F. Papet, 1997. 
livelihood has been called into question by Lao national policies in the last five years.

The "Phunoy" ("small people" in Tai) entity is actually the result of the political and territorial remodelling of the area by the neighbouring Thai populations from the nineteenth century onwards. In the nineteenth century, due to repeated disturbances, the realm of Luang Prabang began to take interest in the territories and populations situated in their confines. Luang Prabang was, indeed, affected by various conflicts: insurrections in the upper regions of the $\mathrm{Ou}$ river; internal wars in the principality of Sipsong Panna; invasions by armed gangs from Yunnan (known by the name of coloured flags, "black", "yellow", etc.) coming along the $\mathrm{Ou}$ river. The Siamese authorities encouraged the king of Luang Prabang to launch a major control policy in his territory through the political reorganization of the meuang satellites and the confirmation of the powers of governors and other competent authorities in the area (Smuckarn and Breazeale, 1988: 59). The inhabitants of the bordering mountainous areas were also the object of integration measures, not only because their control depended on the prosperity of the local Lao elite, but also because these border populations constituted a potential barrier against aggressions from neighbouring principalities The border zones were reorganized through the bestowal of a special status on the mountain groups and, in addition, from the middle of the nineteenth century, the Phunoy language groups were also nominated as border guards. This was accompanied by the handing over of written documents called "The Books of the Land" (peum kongdin, $\mathrm{T})$, which established the limits of the territories for which the groups were responsible. The people in charge of guarding these documents also received the title of "Lords of the Land" (chao thi din, T).

However, the territories drawn up in the "Books" (which shall henceforth in this chapter be referred to as domains), until 1950, were of varying dimensions depending on whether the village at the centre of the domain was on the left or right bank of the Ou river. The left and right bank villages had different external political orientations. Right bank villages had closer connections with the Tai Lu, a Tai federal organization known as Sipsong Panna with whom they had privileged relationships, whereas left bank villages fell under the Lao authority. On the left bank, each village received a manuscript and, therefore, became a domain in its own right. On the right bank, a domain was composed of an "elder" village $(p i, \mathrm{~T})$ and the villages that were said to have evolved from it.
The differences between right and left bank were noticeable on political, ritual and territorial levels. On the right bank, each village was composed of a certain number of localized clans. Among these, most of the ritual and political functions belonged to members of the founding clan, as they could associate their prior history with the territory. Members of the founding clan were given the right to better matrimonial compensations for their daughters' marriages, as well as ownership of the best lands for shifting cultivation - and these lands were hereditary. On the domain level, two doyens, called "Lords of the Land" were entitled to some further specific prerogatives, including the right to lead rituals on behalf of all the villages of the domain (i.e. the domain of the clan of the doyen and, therefore, the clan considered the founder of the oldest village). On the left bank, each village was also composed of several clans, but all of these clans were believed to be founders of the village. Despite the fact that the Lao King of Luang Prabang had handed over the "Books" to only one of the clans, the doyen of each clan was called "Lord of the Land", and these doyens celebrated all together the collective rights devoted to obtaining fertility for the fields and for livestock. Despite the fact that (as on the right bank) the village's lands were divided between each clan, the lands were not owned by anybody in particular and all the families were free to cultivate lands located on another clan's part.

Several decades after their nomination as border guards and the handing over of "The Books of the Land", the differences between the left and right bank populations were further consolidated by the French colonial power, established in this area since the beginning of the twentieth century. On the right bank, a large number of territorial and political restructurings, together with the ennoblement of many dignitaries, perfected the similarities with the Tai meuang: the inhabitants of this territory, called "Meuang Phunoy", were notably exempted from taxes and chores applied to the neighbouring Tai population and were in charge of collecting their own taxes via their ennobled chiefs, called by the Tai title of "Panya". On the left bank, however, the villages were not integrated by such changes.

Even if the right and left bank populations endured similar policies, such as simultaneously being appointed border guards, being given the same "Books" and having some of their members entitled "Lords of the Land", the consequences were quite different on either side of the Ou River. My aim is to understand the reasons for those differences, and I will attempt to show later on in this chapter how those differences 
arose. I argue that they were not a consequence of the left bank villages being isolated from the restructuring of the Meuang Phunoy undertaken by both the royal power and, subsequently, by the colonial government, but were the result of differences in the political territorial organization between the villages located on each side of the river $\mathrm{Ou}$. These differences stemmed from a period before these populations fell under the influence of the Tai population, and they seem to be the result of right bank villages being already organized according to a model quite similar to the Tai one. As such, the dominant powers seem to have preferred to rely on them for the constitution of the Meuang Phunoy.

In order to address this issue, we should first consider the following question: on the right bank, why do domains composed of several villages, dominated by members of the same clan, exist, while they do not on the left bank? The phenomenon I am about to address happened in a rather ancient period, for which there are no available documentary sources. Therefore, I can only proceed by adopting a hypothetical, deductive approach, mostly relying upon the analysis of authors who have worked on neighbouring populations and whose research has been concerned with the comprehension of similar or identical phenomena. By comparing the situations described by these authors, I make the supposition that a number of additional factors seem to be at the root of the creation of right bank possessive domains, as well as the hierarchization process seen there: demographic and territorial pressure, and the practice of scattering on the right bank.

\section{The Economic Data}

Examination of the differences in economic data is the simplest way to explain why a phenomenon of differentiation between individuals, lineages and clans happened in the right bank villages. Tannenbaum (1989: 69), for instance, explains differences in the political organization of lowland Tai societies (the hierarchical) compared with those of the highland populations (acephalous) by the following: in the mountains, the great fluctuation of yields (dependent up amounts of precipitation), the number of workers available to clear a piece of the forest, etc. would represent an unstable base from which sufficient surplus required to secure a stable government could be produced; in the lowlands, the production of such a surplus would be ensured by the existence of regular agricultural production, which was in itself the result of those populations being settled upon territory and owning their own fields.

Phunoy society on the right bank appears to be an intermediate case between these two situations. This is due to the fact that the Phunoy population became fixed in the territory where they settled, as well as the fact that lands would be definitively attributed. Is this the nascent origin, therefore, of that process by which unequal relations emerged? Yet, it seems unlikely that the harvest would have allowed the collection of any surplus, or even that those harvests would have ever been steady; in the 1950's, Harvard-Duclos reported that the lands were still unfertile, despite lying fallow for 50 years, and that only scrub thrived (1959: 8). Nevertheless, in spite of the soil's aridity and the variability of the yields, the Phunoy chiefs could always count on good harvests, as they could depend upon free manpower and could, therefore, produce more than the household consumed and could even release some surplus. Significantly, also, this enabled them to monopolize the ritual functions for sustained fertility. Furthermore, Tannenbaum's analysis does not match the case of the Phunoy. For Tannenbaum, the surplus was the result of favourable ecological conditions and it only consequently allowed some individuals to grow rich and to claim any power. For the Phunoy, on the contrary, it was because the chiefs already had the authority that allowed them to have the population working for them that they had the possibility of obtaining a surplus, despite unfavourable ecological conditions. Nonetheless, it is interesting to remember the fact that the lands were privately owned. This would prevent any redistribution and allow families who owned the most fertile land to gain some surplus regularly; this was a factor that was likely to influence the emergence of group stratification processes. As we will see later, in the left bank villages, where the lands are not appropriated, the organization of the village is relatively egalitarian and the clans do not maintain hierarchical relationships. On the other hand, I will try to show that the fixation of the population on a territory (which, to me, implies to stop looking for new places to move and clear for shifting cultivation) seems to be a factor leading to a greater equality of the clans, contrary to Tannenbaum's assertion.

The wealth gained by an individual, lineage or clan, which would have allowed the latter to establish a differentiation between themselves and others over the long term could yet stem from factors other than agriculture. According to Donohue (1984: 70), the power of the Kachin 
chiefs living in societies organized under the gumsa $a^{3}$ political mode relied upon the exploitation of opium or precious metals; exploitation that would allow them to increase their wealth and to legitimize their authority. Nugent (1982: 516) shares this opinion by asserting that the reason for the weakening of the Kachin chiefs' power at the end of the nineteenth century was a consequence of political and economic changes at the country level. It was, indeed, by preventing the Kachin chiefs from collecting taxes from caravans, practising slavery and rendering them unable to lead raids against the population of the valleys that the British colonial government greatly undermined the chiefs' authority and then, consequently, gumsa social organisation in Kachin society. I can wonder, therefore, if the Phunoy chiefs controlled the trade of some valuables, as the Kachin chiefs used to do, thus gaining a superior economic status upon which they would have based their authority. However, research on this issue does not indicate the control by the Phunoy of any valuables allowing such an evolution. The Phunoy have never been important producers of opium; cultivation of this crop was mainly for self-consumption. Furthermore, in this region, the French military's attention was never drawn to opium cultivation, even though the colonial power was eager to control the opium trade: this bears witness to the low volume of exchanges linked to the opium trade amongst the Phunoy. Neither was there any ore, the exploitation of which would have provided the Phunoy and their chiefs with the kind of profits that some Kachin could get by extracting jade. Although much ore can currently be found in Laos, in the Phongsaly region neither precious metals nor precious stones ${ }^{4}$ could be found at that time. The exploitation of salt, a unique precious mineral resource endemic to the region, belonged to the Tai $\mathrm{Lu}$. As for trade, it was mostly controlled by the Yunnanese caravans that travelled throughout the region. Therefore, there were no locally found resources available, the trading of which the Phunoy could monopolize.

${ }^{3}$ Organization defined by E. Leach as an 'aristocratic' type of organization with a politic entity represented by a territory called mung (c.f. the Shan's mong), governed by a prince of aristocratic origin called the duwa and with the title of Zau (cf. the Sao of the Shan) ([1954] 1972: 83-84).

Refer to A. Bernard (1990) on that subject. The author, who had established a record of the ore for each province of Laos, writes on the subject: "a Dutch, G. Van Wuysthoff, proved that Laos could easily rely on its own metallic products, by analyzing the trade possibilities with Laos, in 1641, selling Indian carpet in exchange for lacquer, gold, and honey. Yet, at the same period, its Company of the Dutch Indies exchanged copper and lead with Cambodia and Annam" (Bernard, 1990: 18).
The Phunoy chiefs were unable to control either the trade in goods or the routes through the mountains. While noticing that it was, indeed, control over the trade routes that rapidly brought power to the Jinghpaw (Kachin), allowing them to become satellite feudal subjects of the Shan princes instead of their serfs, Evans reaches the following conclusion: "In Indochina the comparable groups were enabled to gain control of trade routes and therefore tended to become serfs of the upland Tai" (Evans, 2000: 268). But, no evidence can be found that the Phunoy would loot and take taxes from the Yunnanese caravans, as the Kachin used to do; these practices seem more suited to the Tai population of the valley. The majority of tracks followed by the Yunnanese caravans certainly crossed through the "Salt Route", that is to say, by the valleys that are mostly inhabited by the Tai Lu (called the "Lu furrow") spreading across the northwest to the southwest part of the province. Lefevre-Pontalis (1898: 222) remarked thus in 1894: "[F]or several years Lu and Laotians were fighting for the monopoly of the customs taxes from the border. For the last 6 years it is true that the Laotians seemed to have no control because at the time of the caravans the Lu always arrived before them at the customs points and reaped all the associated monetary benefits, simultaneously, the Lu would treat unfavourably any traders they encountered by chance." A single track, rarely frequented, crossed the Phunoy territory, and its caravans brought iron bars and sulphur to the Phunoy to make hunting powder (Aymé, 1930: 94). Neis also noted that the salt and some of the Chinese textiles owned by the Phunoy were supplied by those Yunnanese caravans (1885: 61). ${ }^{5}$ Rather than sellers, the Phunoy were mostly buyers, and even then, the amount of goods that they purchased has to be put into perspective: "a part of the goods imported by the Chinese, up to Lung Prabang, is only passing in transit through the territory", Aymé added (1930: 98).

Lastly, for Leach, the people of the mountains - and a fortior the chiefs - could still grow richer by becoming mercenaries for the Tai chiefs, or by blackmailing people of the valleys to prevent them from being looted (Leach, 1972: 45-46). Indeed, the Luang Prabang Royal Chronicles acknowledged that the populations from Phongsaly area were regularly enlisted as mercenaries. Moreover, observers from this region (Neis, 1885), as well as the Phunoy or Lu accounts, mention the conflicting relationships between Tai Lu and the Phunoy. But, what

However, old people of the right bank and left bank villages recall the long trips taken by their parents to stock up on salt in the Tai Lu villages. 
was at stake in the war that led the two groups against each other? Was it regarding the control of the roads, about "blackmail", about loot, and, in any case, was it a way to gain enough surpluses to ensure the power of the chiefs? It is not possible to determine the answers to these questions at this time.

The economic factors, then, are either not sufficient or not well documented enough to allow us to draw a conclusion about the formation of the right bank domains and the acquisition of prerogatives by their chiefs. On the other hand, two issues attract our attention: the terminal settlement point of the populations and the inequitable allocation of lands, which were both described by Tannenbaum (1989) as factors contributing to long-term hierarchy amidst a society. Yet, analysis of the accounts concerning the foundation of the right bank villages implies that these two issues were the result of the scattering process and of the constitution of domains, two phenomena not present in the left bank villages. Examination of accounts concerning the foundations of both right and left bank villages may provide insights into the relationship between scattering, domain constitution, settlement of populations and attribution of lands.

The Foundation Agcounts: The Absence or Regurrence of the Phenomena of Village Segession

On the right bank, whenever one asks how the villages and domains have been founded, the villagers generally relate a stereotypical discourse that seems to be connected to a pre-established model: the domains are composed of different villages, and the clan acknowledged as the founder of the oldest village of this domain is said to rule it. Generally, whenever tensions led to a confrontation between the chief of the village and his younger brother, the latter would question the authority of the former and leave the village, to be followed by some relatives and allies, after which they would found their own community. ${ }^{6}$ This process of secession could be repeated, either from the root village or from a village that had already split from the root village. In all cases,

${ }^{6}$ Leach notes a similar fragmentation process in the Kachin's society with the following difference: because of the ultimogeniture principle, the younger brother retains the authority and therefore, it is the elder brother who tries to escape it by leaving and founding a new village. the same principal ruled the foundation of the new village: a member of the clan who founded the village of origin established his own community following a dissension. As a result, the clans that founded all the seceding villages were supposed to be the same, in as much as the conflicts always involved the brothers belonging to the clan that founded the root village.

The model of village foundation illustrated by the accounts seems to be verified in a number of cases. For example, the clan that founded the village of Houeylu is the same as the clan that founded the village it stemmed from, Ban Namhung; in the same way, the villages of Kunum Noy and Kunum Luang were founded by several clans that left Tapat village, and those clans happen to bear the same name, Siman, which is, indeed, the name of the clan that founded Tapat village. However, in some other villages, while the villagers do describe the origin of their village as the result of a split between two brothers, the elder and the younger, it seems that the founding clan of the village is different from the clan of the root village from which it had split. For example, the people of Thongpi village affirm that the Lawa clan is the founding clan of their village, whereas people from Xai village, while also founded by some families from Thongpi, think that the founding clan of their village is the Putin clan. This discourse does, therefore, contradict the facts in the aforementioned example (whenever this contradiction is brought up, the villagers remain evasive, usually stating that they are only repeating what they have been told by their ancestors). Let us consider as well the instructive example of Kiupork village. This village was founded rather recently, and the accurate memory of that event, as it was relayed to me, suggests to me that the account has not been excessively distorted. One old man from this village related the following: "Before, there was not enough land in the former village. All the poorest families finally took the decision to leave and settle on the other side of the hill. It has been really difficult. When the move happened, people were panicking, they did not know what to do and my grandfather organized everything. At the beginning, no one would listen but then, people did, and as everything went quite well, after they settled in the village, people asked him to be the chief". According to this account, the chief was not elected because of his lineage but because of his demonstrated leadership qualities and personal charisma. I may add also that in most right bank villages, alternative versions of the foundation stories are recounted during ceremonies dedicated to the spirits of Sky and the Earth (motha dat, mithon dat, P), and these versions 
obviously contradict the normative accounts such as were presented earlier. While accomplishing these rites, old people tell that their villages were founded by two or three clans (angtchu-angtcheu $\mathrm{P}$ - two clans being the minimum required) with those clans sharing the ritualistic functions and ensuring that fertility would be obtained. These founding clans are, therefore, considered equal: none of them obtain any supremacy and the accounts make no mention of any special leaders from the group.

The particular manner by which villages are founded after some dissension between the elder and younger brother seems to be more a normative model recorded by the accounts than a constant sociological reality. Yet, whether a village was founded by a member of the clan of the root village or by another clan, it will systematically be depicted as the "younger" (nong, T) village in reference to the root village, thus called "elder" (ay, T). Whenever people are asked the reason why the name of the "younger" village founding clan is different from that of the root village, the answer is often that, indeed, it used to be the same, but that the clan split when the younger brother left the root village to found a new one. Thus, the Pongam clan used to be a part of the Lawa clan; in the same way, the Tongmumuya and Tongmumuba clans were originally the exact same clan. It is, therefore, possible to keep the ideal, according to which the founding clan of the root village is to be necessarily the founder of the other villages - the villages thus representing its domain.

The principle by which a hierarchical distinction operates between the founding clan and the others allows the Phunoy to justify why clans of the same village cannot have access to the same lands, nor have the same rights. The founding clan, which would have the best lands and would request better matrimonial allowances for its daughters, was also in charge of the ritual functions of the group (let us remember that it was also the founding clan of the domain that provided the "Lords of the Land" who were in charge of the rituals ensuring the obtaining of fertility for all of the villages belonging to their domains). The appropriation of the best lands would be justified by the fact that the founding clan would distribute the plots between each of the clans of the village, or by the fact that the first clan to arrive had chosen the best lands, leaving no choice to the last clans that had settled who were thus allocated the less fertile lands.

This phenomenon of village division led to the distinction between founding clans at the domain and village level and is not dissimilar to the organization found in neighbouring Tai Lu villages. Moreover, it should be noted that the terms employed to describe the area occupied by each village within the Phunoy domain are of Tai origin. In the aforementioned cases, all the villages of one meuang are said to stem from the central village of this meuang. Let us consider the case of the Tai Lu villages of Bun Neua and Yo, respectively centres of their meuang. These two villages, considered to be the first villages of those meuang, were respectively called "father" and "mother" villages (ban pho, ban ma, $\mathrm{T}$ ), as they are supposed to have been founded by common ancestors. This is given as the explanation as to why the inhabitants of the two villages are not allowed to marry. The other Tai Lu villages, which are a part of the two meuang, were called "younger villages" (ban nong, $\mathrm{T})$. Each of them is always composed of two clans (sing, T) organized hierarchically, as one is commonly designated "the chief clan" (sing nay, T) whereas the other one is called the "deputy clan" (sing hong, T). The functions of chiefs and officials for the rituals addressing the spirit of the meuang (phi meuang, T) were exclusively reserved for members of the "father" and "mother" villages' founding clans.

Two types of account are, therefore, to be found in the right bank villages: stories of domain foundation depicting inequities between clans (one of which has to be systematically the founder); alternatively, stories of village foundation where the clans are said to share equally the ritual functions. How to explain the opposition between those two types of account?

Agcounts of Foundation on the Left Bank: The Pre-Eminence of the Chief and the Equality of the Clans

This contradictory set of explanations for the manner by which villages and domains were founded (sometimes the equality of the clans at the time of the foundation being insisted upon and, at others, the pre-eminence of the founding clan and its chief), can equally be found in the left bank villages. The only difference is that, unlike the right bank accounts where there is typically one dominant version and the

7 The name of those clans can change. The opposition between the "chief clan" and the "deputy clan" is a specificity of the Yo village, but people from Bun Neua oppose the Phy a clan to the Pee clan: there are both titles of nobility and the second one would be less important than the first one. I refer here to the qualifying terms as those clans also have names that can be tree (sing $l 0$ ) or animal (sing vang, the tiger) names. 
other version is given only as an alternative, on the left bank, these two kinds of explanation are given in the same story. The structure of these accounts is always the same, involving three characters who are the founders of the village as well as being the ancestors of the three clans who habitually comprise the village population. Take for example the story of the foundation of Kiu village: "One day, three hunters, Tao Khamsuk, Nyeum Phiban and Tao Pusum, departed for the forest. They were then attracted by a light that seemed to be requesting them to follow it. While chasing this light, they reached a clearing abounding with water. They decided to found a village at that location and are said to be the ancestors of the three clans: Keutchup, Tcheumang and Mantcha. Tao Khamsuk was the chief, Nyeum Phiban was his second, and Tao Pussum the layman in charge of the pagoda". ${ }^{8}$ In these stories, the ancestors of all the clans of a village, always three persons, simultaneously found the locality: none of the clans can claim the status of founding clan. Yet, most of the time, those stories will tend to set a clan apart from the others - in this case, the clan of the chief.

At the time of the handover of the "Books", however, when the village was transformed into a domain, the slight differentiation between clans just noted does not become accentuated. First, I should emphasize that the domains located on the left bank differ from those on the right bank on account of their size. The inhabitants of the left bank villages explain it by the fact that their villages do not stem from the secession of other villages and that they have never been split. ${ }^{9}$ This situation contrasts markedly with the right bank villages, where even today the people are able to trace precisely the origin of each village, its successive moves, the root village from which it originated and whether it has been divided subsequently into other village units. Yet, we have seen that it is the reference to those villages' secession stories that justifies a

3 This account with these three clans is sometimes told in a different way: the first clan would be the clan of the "good deaths", the second the one of the "bad deaths" and the third one would have been in charge of separating them from each other. It is interesting to note that those separations of the clans in three functions can also be found in some of the founding accounts of the right bank. It is also said that one clan is the equivalent of the water, the other one of earth, and that the third one's role is to maintain the balance between them. This may be a way to underline the necessity of a three-fold exchange, two terms being opposed, the third one contributes necessity of a thro

a regulator. bank: around a hundred houses (versus an average of 40 houses only on the right bank). hierarchy between the clans and the villages within Phunoy society on the right bank. On the left bank, one cannot find domains composed of several villages and, as a consequence, the ritual predominance of one clan upon a group of villages does not exist, as do neither any Lords of the Land at the supra-village level: each left bank village is a small domain in its own right. Therefore, when the King of Luang Prabang sent the "Books of the Land", the books were handed over to the clan that was only slightly distinguished amongst the three and the "Lords of the Land" function was shared by all of them: among each of the three clans, there was a "Lord of the Land". In the same way, those "Books" handed over by the king were decreed to be the property of the all the clans of the village, and all the clans had the same rights upon the lands cultivated by their members: for all land tenure, matrimonial compensations, and religious and political functions, the clans were nearly equal after the "Books" were handed over, with only a slight ritual pre-eminence being accorded to a descendent of the founding "chief". Lastly, it should be said that any person from outside the village who intended to settle in it, had necessarily to become affiliated to one of the three existing clans, losing as a consequence his own regional clan identity. ${ }^{10}$ Whatever was the motivation for this practice within the left bank villages, a non-differentiation between the founding clans and the new settlers was the main result (differentiation could certainly have happened if the newcomers were to retain their former clan of origin). The absence of political and economic distinctions between the different clans in the same village, as well as between different villages on the left bank, whether occurring on the discursive or on the practical level and, furthermore, despite the intervention of external powers in the nomination of border guards and handing over of territorial documentation such as "The Books of the Land", gives the impression that any process to institute a hierarchy or differentiation in the left bank villages encountered a sort of resistance.

We can see the similarities between the different accounts regarding village foundation on the right bank and those of the left; it is mostly the accounts referring to domain foundation that tend to change. The right bank Phunoy accounts emphasize equality between clans at the

${ }^{10} \mathrm{I}$ do not know how those names are being adopted and what is the status of the families newly included. Anyway, this practice, together with the fact that the villages did not scatter, explains why the clans are always different from one village to another. 
time when the village was founded, the clans establishing the village sharing the ritual functions according to a complementary principle, but also, progressively, inequality begins to emerge with the constitution of the domain. At that time, the prerogatives of the founding clan of the eldest village increase and emphasize a hierarchy within each village and within the domain. These developments, presented in two distinct accounts on the right bank, are united in the same story in the left bank villages, where the equality of the clans (all founders) and the pre-eminence of the clan of the chief are presented all together. This becomes evident from the fact that, on one hand, all the clans have equal access to the land and each doyen of a clan is equally titled "Lord of the Land", but on the other hand, there is a ritual pre-eminence for the members of the founding clan of the 'chief'.

To conclude this point, it seems that the scattering process indeed favoured the constitution of the domains. The "Books of the Land" were afterwards handed over to members of the lineages derived from the elder brother of the clans considered founders of the root villages (i.e., from which other villages located in the domain would have split). Thereafter, a periodic ritual was performed by these individuals, called "Lords of the Land", for the obtaining of fertility in villages in their domain. In situations where there was no scattering from a village, as is the case in the majority of the left bank villages, the "Lords of the Land" would only be in control of their own village space. The main difference existing between the right and the left bank villages is, therefore, the fact that, for the latter, the title "Lord of the Land" was given to all the clan chiefs.

Therefore, the scattering process (or its absence) provoked a lot of distinctions between the two groups of villages situated on the right and left bank. On the right bank, the clans split to become, in each village, localized clans, whereas on the left bank, a clan was only represented in one village; on the right bank, wherever the villages and the clans were split up and the predominate ideology was connected to younger/ elder and first/last settlers, great differences between clans and lineages appeared. In the opposite case, on the left bank, an acephalous village society predominated based upon clan equality.
Scattering, Institution of Glan Hierarchies and Pressure UPON THE LAND

Even though the scattering process indeed seems to have been central to the formation of right bank domains, it cannot be established as the only explanation for the creation of those territories, nor is it a sufficient datum to understand how, later on, those domains persisted. Yet, in the Phongsaly region, other villages experienced a similar scattering phenomenon without the appearance of any root village pre-eminence over other villages, nor the creation of hierarchy between the units in the domain relationship. For instance, the inhabitants of the Akha ${ }^{11}$ villages of Chakhamsaw and Chakhamdeng (Bun Tai district), where I conducted research, affirmed that they were descendents of Sanor village, but they never found themselves in a situation of subordination, ritual or political, towards Sanor. This is also true for some villages with small groups of Phunoy language speakers: according to its people, the "Pumon" village split up a century ago into two smaller agglomerations that became independent from their village of origin; the same thing happened to the five Laopan villages located in the districts of Bun Tai and Samphanh, all supposedly originating from the same village. Similar phenomena can be found as well in some other provinces of Laos: Izikowitz (2001: 41) noted that Lamet villages were of a tiny size and that this was a consequence of regular divisions. Lastly, the Phunoy left bank villages most likely originated from the right bank villages - even if they have no common memory of it.

In order to explain the fact that every scattering process does not necessarily involve the constitution of a domain, I am willing to present the analysis proposed by Leach for the Kachin example. For Leach, the fact that in Kachin society some villages live in an autonomous fashion, whilst others are gathered into agglomerations subordinated to a root village, is mainly the consequence of a scattering process combined with population increase and land shortage. Leach writes: "Wherever the density of the population is remarkably low, the very small autonomous villages are the big majority; the chief of each of these villages claims his own independence.... In the regions where the density of the population is higher, then there is no way for the sons of the chief to establish some independent domains without stepping on the rights,

"Another important ethnic group of Tibeto-Burmese speakers in northern Laos. 
already existing and acknowledged, of some other chief. In that case, whoever decides to move anyway would have no other choice but to settle on a relative's domain, with a status of subordinate" (1972: 202). According to Leach, the traditional way of resolving conflicts and the will to be apart from a chief's supervision are linked to population increase and land shortage, inasmuch as the absence of free space suitable for cultivation will not allow for the foundation of new communities. Kirsch shows complete agreement with this theory by asserting that, in a context where demographic pressure is low, departures from the village facilitate the levelling of differences within the root villages themselves: "Older sons of a 'chief' set up 'colonies'... draining off some of the more highly motivated from the parent village--leaving the less motivated behind" (1973: 29).

These alternative propositions seem, at first glance, to fit the situations of both right and left bank villages perfectly well. The territory occupied by the right bank Phunoy, more or less equivalent to the south of Phongsaly district, was densely populated (this was before the great migration movement of the 1960's that affected the region). According to Roux, in 1924 the Meuang Phunoy was composed of thirty-six villages, whilst there were twenty-eight in the same zone in $2003 .{ }^{12}$ Furthermore, not only were the villages in 1924 more numerous than today, they were also larger: "Whereas the most populated of the villages belonging to other races do not exceed ten shacks, most of the P'u-noi housing schemes are composed of more than 50 shacks" (Roux 1924: 456). Some other French observers at the beginning of the century made similar remarks: the Nam Pung village was composed of sixty to eighty houses (Guillemet and O'Kelly, 1911), Phongsaly village, more than one hundred and fifty (Cheyrou-Lagreze, 1921).

On the contrary, demographic and territorial pressure on the left bank of the Ou River seems to have been extremely low. The left bank villages are more recent than those on the right bank (Alexandre and Eberhardt, 1998: 51); some inhabitants even affirmed that their ancestors came from the right bank, even though none of them could remember precisely which village they had come from. Maps of the

${ }^{12}$ I have taken into consideration for 2003 the area that corresponds to the ancient limits of the Meuang Phunoy in 1924; I have subtracted from the 2003 numbers the number of habitants of the Phongsek village (that was not included in $\mathrm{H}$. Roux in the Meuang Phunoy) as well as the number of habitants of the villages that originated from it and settled by the Ou River bank (Hatkao in 1970, Hatao in 2001). region designed by the French at the start of the twentieth century only indicate the big villages and do not mention those on the left bank. We can, therefore, make the supposition that, at that time, demographic and territorial pressure was not an issue at all.

One exception among the left bank villages to the general absence of hierarchical development as a result of scattering should be mentioned: the people of the "Sen Sukhwa the Great" (Sen Sukhwa Luang) told me in 2002 that eighty years ago (meaning the year 1920), conflict arose between the chief of the village and his younger brother. They shared open "Books of the Land" (composed, as previously mentioned, of two parts: the official letter and the description of the territorial limits). The youngest left and founded a new village, called "Sen Sukhwa the Little" (Sen Sukhwa Noy). The inhabitants of this village belonged to three different clans, but it was only from within the clan of the younger brother that a person could be acknowledged as "Lord of the Land". This person (and his descendants) was, therefore, the only one entitled to proceed annually to the division of the plots between each household before slash and burn of the forest. The two villages, which formed the same domain according to their inhabitants, celebrated a common cult every five years for the obtaining of fertility for the fields in the forest located at the border of the two villages. The way the two villages of Sen Sukhwa are organized strongly reminds us of the organization of villages on the right bank of the Ou River. The founding clan is entitled to the ritual prerogatives, and the title "Lord of the Land" can only be bestowed upon one of its representatives. Here, indeed, is a scattering process leading to the creation of a clan's domain and the institution of a clan hierarchy.

But, how do we explain the subordination of the Sen Sukhwa Noy village to the root village in spite of the fact that, with territorial pressure on the left bank being low, this village could have settled independently on another place, at least according to the process described by Leach? Does it mean that my previous conclusion concerning the significance of very low demographic and territorial pressure upon the left bank could be incorrect? If so, what could explain why such scattering processes did not occur in other villages of the left bank? Moreover, nowadays, demographic and territorial pressure has become extremely important on the left bank: each village is composed of almost one hundred families and are often located in close proximity to one another; yet even so, they still do not scatter. I shall now consider this problem before re-examining the singular case of Sen Sukhwa village. 
Fixation in Territory Delineated by the "Books of the Land"

The most likely hypothesis to explain why the left bank villages did not scatter is provided by the handover of the "Books of the Land" by the royal power: the delineation and allocation of the land was divided up between the pre-existing villages, preventing the foundation of a new village on non-monopolized lands.

When the "Books of the Land" were handed-over, on the right bank they delineated a territory already marked by the scattering process (a model of elder and younger villages). The pressure on the land being ancient, the villages that were newly founded had to settle on the territory of the villages from which they originated. ${ }^{13}$ These new villages would have kept the original cult location, as the favoured spirit of the founding clan brought its protection to the entire group of villages in the territory. In this way, we can surmise that the cult strengthened the prestige (power, prerogatives) of the founding clan of the original village from which the cult originated, not only over the inhabitants of the root village but subsequently, following division, for both villages. Thus, scattering, within the same territory, reinforced the ritual pre-eminence of a clan that, from thenceforth, accomplished the cultic rituals for a group of villages and clans. The handover of the "Books" would have been a consequence of the pre-existing belief in the pre-eminence of the supra-village founding clan. On the contrary, because of the low demographic density due to the recent settlement of the inhabitants, on the left bank each village formed an autonomous entity and, thus, constituted a domain of its own. ${ }^{14}$

In fact, the scattering process has been rarely in operation since the handover of the "Books". By comparing the maps drawn up by the French during the twentieth century with those more recent maps made in the last decade, we notice that the villages did not scatter

${ }^{13}$ It is most likely that these new villages were, in fact, the small field house of a root village and later, would have formed an autonomous group. H. Roux noticed, at the beginning of the 20th century, that: "each village is divided in 2 parts: the original village, which never moves, and the village of cultivations, where the adults, the women, a part of the livestock and other pet animals settle during the entire length of the work in the fields." (1924: 457).

it While discussing with the left bank villagers, they found it difficult to imagine that, in the past, a village would have to split up as, in their opinion "the space to cultivate was important enough, there was no reason to leave the village". any more, neither did they spontaneously move, or, if they did, it was always within their domain. ${ }^{15}$

We can, therefore, suppose that it is this "fixation" of territory that prevented the phenomenon of splitting in the villages of the left bank. The fact that the territory of each village was fixed by the "Books of the Land"-leading to the allocation of all the lands in spite of the absence of any pressure on the land - did not enable the village to split. The case of Sen Sukhwa Noy shows that it was possible to form a new village, even if it had no other option but to settle on the lands of the village from which it stemmed. Why did such a similar phenomenon not occur more often on the left bank or, supposing that it did, why did the inhabitants not recall the ancient divisions?

It seems that the handover of the "Books" not only delineated a zone (composed either of several villages or of one), but also attributed some functions (those of the "Lords of the Land") and contributed to the mode of social organization as well. This type of organization being, on the left bank, equitable, scattering did not become necessary, as there was no conflict with authority. Indeed, it was because the scattering process did not begin in the left bank villages that no supra-village organization existed and each village was, therefore, autonomous at a political and ritual level. When the "Books" were given, the clan of the founding chief only had prerogatives upon his own village and the difference with the other clans was not so pronounced. The "Books", therefore, would have reinforced an egalitarian system within left bank society. The role of the chief being small (he only had ritual prerogatives), and decisions being taken by the council of elders and all the clans, via their doyens, being charged with the control of the field's fertility rites, there was not any singular authority to be questioned, and then, no reason for leaving the village. ${ }^{16}$

${ }^{15}$ The Khunsuk village, located at the North of Phongsaly town, did split up 80 or 90 years ago, according to its inhabitants. The village resulting from the scission did settle on the territory of the original village.

${ }^{16}$ This idea of an equality between the clans considered as necessary is still widespread nowadays, even if the left bank villages endure a pressure on the land more important than it has ever been on the right bank ones. However, the inhabitants keep explaining the scattering of the plots and their free allocation by the fact that "it has always been like that, because there has always been much space for the shifting cultiva tion". The ideas, here prevail over the fats. refusal of a monopolized control on the production by a minority via the plots' repartition, as this latter leads to the instauration of a hierarchy between the families. 
The equality between the clans might have been reinforced because of the impossibility of founding a new community on the lands of the root village. Indeed, this model seems appropriate to similar situations within other highland populations: the lands being fixed (and with no split in the village), the members most likely to question a chief's authority and who, if they had not been confronted by land pressure would have left and founded new communities, instead have no choice but to question the authority of the village chief (Kirsch, 1973: 29-30). This results in a decrease in the status differences within a village, the chief's authority fades to the benefit of the village assembly, even though the founding clan can still be symbolically acknowledged (Bouchery, 1988: 301). Whether such villages are egalitarian from the start or become so following a democratization process (due to the progressive loss of distinction between the founding clan and the others), the lands, together with the ritual and political functions, become more fairly divided between all the clans. Because of this 'democratic' mindset, potential agents of conflict would be less likely to question authority or leave the village.

\section{The Impact of the Colonial Power}

Finally, we still have to comprehend the sole village division that occurred on the left bank: the Sen Sukhwa division. Towards that goal, let us examine some contingent events. At the beginning of the twentieth century, the left bank villages, isolated from the military posts and barely indicated on the maps, were not of any interest to the French settled in the region, and the administration of the zone was left to the Lao dignitaries of the meuang Hun. But, in the 1920s the colonial administration took the decision to build a track to link together Phongsaly city (which then became the county town of the 5th French Military Territory in 1929) with Dien Bien Phu. This track passed through the territory of the left bank Phunoy but close by only one village, Sen Sukhwa, which, therefore, became a possible stopover on this long route. The French then decided to ensure that this village would be a safe stopover whilst in transit through this region. In order to ensure the loyalty of the village and the proper functioning of the authoriiies, they entitled the chief of Sen Sukhwa village to become chief of the two villages of Sen Sukhwa, and gave him some advantages; the chief remained the meuang Hun chief's subordinate and his authority did not exceed the limits of his own village (Mordant, 1934: 874). Nowadays, the inhabitants of Sen Sukhwa Noy relate that dissensions in the village resulted from the nomination of the chief of the village to this prestigious role: "In Sen Sukhwa Luang the family of the chief of the village did not pay taxes, so the others became irate, the younger challenged his brother to a fight and, followed by the malcontents, he came here to avoid the taxes". The reasons why some families left and settled in a new location would have been caused by unequal relations, newly instituted. However, it was not to seek a more egalitarian environment that the younger brother of the chief would have taken the decision to migrate: unlike the accounts of other left bank villages, the foundation of Sen Sukhwa Noy reported a unique founder. The sole clan to be considered that of the chief was the clan directly related to the man who founded the village, and his representative was the unique bearer of the title "Lord of the Land" and holder of the "Book of the Land". The two villages of Sen Sukhwa Luang and Sen Sukhwa Noy, the clan of the "Lord of the Land" being the same (the clan of both the elder and younger brothers), were a part of that clan's domain and this dominant clan benefited from certain prerogatives. Therefore, it seems probable that the scattering reinforced the status of the dominant clan in the original village. This was achieved firstly by increasing the ritual authority of the chief of that village, and secondly by the fact that the new village was founded by a member of the same clan as this chief, thus illustrating further the capacity of the chief's family members to assume the responsibilities of leadership.

The case of the two Sen Sukhwa villages is, therefore, a pertinent illustration of how external intervention, in this case by the French colonial administration, could introduce a hierarchy among the clans. However, the new communist government of the Pathet Lao abolished the privileges of these chiefs in the 1960s, and the socio-political organization established previously progressively collapsed. ${ }^{17}$ In this village today, the hierarchy between the clans, which used to be visible through the fact that the "Books" and the title "Lord of the Land" belonged to the representative of only one clan, is no longer seen. Unlike the other left bank villages where the doyens of each clan still maintain the title of "Lord of the Land", there is no longer a representative bearing

After the Geneva agreement in 1954, the communist forces of the Pathet Lao held the government of the province of Phongsaly. 
this title, nor is there a ceremony to celebrate this function in either of the two villages of Sen Sukhwa. In Sen Sukhwa Noy it is said that the "Book" became something negative, dangerous for its owner and his family, and it was consequently taken to the pagoda to neutralize its evil powers. As for the "Book" of the root village (Sen Sukhwa Luang), it underwent a similar process: "The other villagers used to tell me that it was my 'Book', and that it was not for them to deal with nor should they participate in the rites. Me, I did not want to celebrate the rites on my own: if, for instance, I could not produce enough offerings to present, it becomes too dangerous for me and my family. So, I buried it in the wood to get rid of it" its former owner relates. ${ }^{18}$

$$
* * *
$$

When the "Books of the Land" were handed over to populations speaking the Phunoy language, who were also given the role of border guards, the Phunoy encountered different situations depending on the locality. In the villages on the right bank of the river $\mathrm{Ou}$, populated by more ancient inhabitants, there already existed a hierarchy, probably arising from the process by which villages split, combined with pressure upon the land. Local representations reinforced the distinction between elder/younger and first/last settlers, and established the division process as a constituent of the pre-eminence of one clan over the others. On the contrary, in the villages on the left bank, which was a zone more recently populated, no hierarchy existed between the clans in spite of the ritual pre-eminence of the representative of the founding clan: the "Books" were divided between the clans of the village, and a member of each clan bore the title "Lord of the Land". The "Books", therefore, did not have the same effect. By fixing the populations on the territory that was allocated to them, they confirmed a reality: the hierarchy of the right bank clans and, conversely, the absence of hierarchy on the left bank. It must be noted in this context, the royal power and, at the start of the twentieth century, the colonial administration, relied more upon populations that represented, according to their assumptions, a hierarchically organized system, closer to their own concepts of authority, and it was these populations who, thus, assisted them in their control of the region-the ones of the right bank.

${ }^{18}$ This interview was given during my field enquiries in 2002.

PART THREE

THE KACHIN SUBGROUPS 